Check for updates

Cite this: RSC Adv., 2018, 8, 38036

\title{
Effects of Maillard-type caseinate glycation on the preventive action of caseinate digests in acrylamide-induced intestinal barrier dysfunction in IEC- 6 cells
}

\begin{abstract}
Jia Shi, ${ }^{a}$ Yu Fu ${ }^{b}$ and Xin-Huai Zhao (DD *a
Dietary acrylamide has attracted widespread concern due to its toxic effects; however, its adverse impact on the intestines is less assessed. Protein glycation of the Maillard-type is widely used for property modification, but its potential effect on preventive efficacy of protein digest against the acrylamide-induced intestinal barrier dysfunction is quite unknown. Caseinate was thus glycated with lactose. Two tryptic digests from the glycated caseinate and untreated caseinate (namely GCN digest and CN digest) were then assessed for their protective effects against acrylamide-induced intestinal barrier dysfunction in the IEC- 6 cell model. The results showed that acrylamide at $1.25-10 \mathrm{mmol} \mathrm{L}{ }^{-1}$ dose-dependently had cytotoxic effects on IEC- 6 cells, leading to decreased cell viability and increased lactate dehydrogenase release. Acrylamide also brought about barrier dysfunction, including decreased trans-epithelial electrical resistance (TEER) value and increased epithelial permeability. However, the two digests at $12.5-100 \mu \mathrm{g} \mathrm{mL}^{-1}$ could alleviate this dysfunction via enhancing cell viability by $70.2-83.9 \%$, partly restoring TEER values, and decreasing epithelial permeability from $100 \%$ to $76.6-94.1 \%$. The two digests at $25 \mu \mathrm{g} \mathrm{mL}^{-1}$ strengthened the tight junctions via increasing tight junction proteins ZO-1, occludin, and claudin-1 expression by $11.5-68.6 \%$. However, the results also suggested that the GCN digest always showed lower protective efficacy than the $\mathrm{CN}$ digest in the cells. It is concluded that Maillard-type caseinate glycation with lactose endows the resultant tryptic digest with impaired preventive effect against acrylamide-induced intestinal barrier dysfunction, highlighting another adverse

effect of the Maillard reaction on food proteins.
\end{abstract}

Received 30th September 2018 Accepted 6th November 2018

DOI: $10.1039 / c 8 \mathrm{ra0} 8103 d$

rsc.li/rsc-advances

\section{Introduction}

Acrylamide, a water-soluble vinyl monomer, can be produced during high-temperature food processing, and has several toxic effects in the body. ${ }^{1}$ In general, acrylamide as a dietary toxicant can cause neurotoxicity, genotoxicity, reproductive toxicity, and even carcinogenicity in both animals and humans. The acrylamide-induced cytotoxicity usually occurs via oxidative stress. ${ }^{2,3}$ Acrylamide from the diet can be rapidly absorbed to a high degree in the intestines and then converted into epoxide glycidamide. ${ }^{4,5}$ It is evident that the maternal acrylamide has a negative effect on the small intestine histomorphometry of guinea pig offspring, ${ }^{6}$ and can increase the numbers of total, divided, inactive crypts, and damaged villi in the duodenum and jejunum. ${ }^{7}$ Intestinal absorptive surface can also be affected by acrylamide in the jejunum. ${ }^{6}$ Thus, potential harmful effects of acrylamide on the body health can not be ignored. Two

${ }^{a}$ Key Laboratory of Dairy Science, Ministry of Education, Northeast Agricultural University, Harbin 150030, PR China. E-mail: zhaoxh@neau.edu.cn; xhzhao63@ sina.com.cn; Fax: +86451 55190340; Tel: +8645155191813

${ }^{b}$ Department of Food Science, Faculty of Science, University of Copenhagen, Frederiksberg 1958, Denmark previous studies had shown that acrylamide could induce the loss of tight junction (TJ) integrity, leading to intestinal barrier dysfunction with subsequent translocation of luminal substances (such as bacterial endotoxins) into the portal circulation and consequently intestinal injury., 8

Intestinal barrier function is closely related to intestinal health and disease prevention. Intestinal epithelial cells serve as the first line of defense against pathogens, and play an important role in the maintenance of gut barrier function. ${ }^{10}$ Intestinal transport and barrier function are established by a layer of epithelial cells. These cells are linked together by the TJ strands, which govern epithelial permeability and integrity. ${ }^{11,12}$ Intestinal mucosal integrity and permeability are regulated by physiological and environmental factors, such as heat stress and other physical stressors, pathogenic microorganisms, age, and dietary factors. ${ }^{13,14}$ Barrier function of the intestine is highly regulated by TJ proteins, allowing the epithelium to control the transmucosal permeability to water, electrolytes, and smaller solutes. Among these TJ proteins are occludin, junction adhesion molecule $\mathrm{A}$, claudins, and zonula occludens proteins (ZO-1 and ZO-2), which connect adjacent cells and build the intestinal barrier. ${ }^{15}$ TJ defects implicate the 
pathogenesis of a number of intestinal diseases like sepsis, inflammatory bowel disease, and bacteria-induced diarrhea. ${ }^{\mathbf{1 6 , 1 7}}$ Barrier defects in disease pathogenesis result from the altered expression of TJ proteins. ${ }^{18}$ Claudins are the main proteins regulating TJ functions. ${ }^{19}$ Occludin (the first identified transmembrane TJ protein) plays a critical role in maintaining $\mathrm{TJ}$ barrier function. ${ }^{20}$ Occludin as an invariant component is expressed in almost epithelial TJ structures. ${ }^{21}$ Zonula occludens, a belt-like region to contact the polarized epithelial cells, behave as a selective barrier to the small molecules but a total barrier to the large molecules. ${ }^{22} \mathrm{ZO}-1$ is a structural and functional marker of epithelial TJs. ${ }^{23}$ These TJ proteins are thus widely assessed to reflect epithelial barrier function.

Milk proteins upon digestion will generate numerous peptides with various biofunctions. ${ }^{\mathbf{2 4 , 2 5}}$ Bioactive peptides are usually prepared with various proteases, including gastrointestinal enzymes (pepsin and trypsin). In general, both amino acid compositions and sequences are important to the activities of bioactive peptides (or protein hydrolysates). ${ }^{26}$ During milk processing, the caseins are susceptive to the Maillard reaction and thus can be glycated with lactose. Maillard-type protein glycation enhances functional properties of the proteins. ${ }^{27}$ However, it is well-known that the Maillard reaction has some negative impacts on both nutrition and quality of the processed foods due to the formation of undesired colour and flavor products and especially toxic/mutagenic compounds, together with partially reduced bioavailability of the essential amino acids. $^{28,29}$ Moreover, there is an increasing trend in the consumption of the processed food around the world. The intake and absorption of the Maillard reaction products (especially the advanced glycation end-products, AGEs) thus deserves special attention, because dietary AGEs intake is unavoidable and AGEs can act as seeds for the in vivo formation of other products. ${ }^{30}$ To the best of our knowledge, very few data are available on the effects of casein glycation on native caseins or casein digests activities, so its study deserves consideration in scientific community.

Some luminal factors including food components can affect barrier function of the intestinal epithelium via TJ modulation. Beta-casofensin generated from bovine $\beta$-casein has a preventive effect against the indomethacin-induced intestinal lesions, and thus preserves goblet cells and improves wound healing. ${ }^{31}$ Other components such as oligosaccharides, oxyresveratrol, quercetin, and resveratrol also have a similar protective effect. $^{32-35}$ This study thus assessed and compared the protective efficacy of two tryptic caseinate digests against the acrylamideinduced epithelial barrier dysfunction in a cell model (rat small intestine epithelium IEC-6 cells) via evaluating intestinal epithelial integrity and intercellular TJ protein expression. One tryptic caseinate digest (namely $\mathrm{CN}$ digest) was yielded from commercial caseinate and served as control. Another digest (namely GCN digest) was generated from a lactose-glycated caseinate of the Maillard-type. This study aimed to provide a novel insight into the Maillard-type protein glycation, verifying if this reaction might confer tryptic digest with changed protective efficacy against the induced epithelial barrier dysfunction.

\section{Materials and methods}

\section{Materials}

Caseinate (protein content of $984.2 \mathrm{~g} \mathrm{~kg}^{-1}$ on dry basis), Dlactose, acrylamide (purity > 99\%), bovine insulin, four kilo dalton fluorescein isothiocyanate-dextran (FD-4), bovine serum albumin (BSA), and Dulbecco's modified Eagle's medium (DMEM) were purchased from Sigma-Aldrich Co. (St. Louis, MO, USA). Phosphate-buffered saline (PBS) was bought from Solarbio Science and Technology Co. Ltd. (Beijing, China). Trypsin (EC 3.4.21.4) with an activity of $120 \mathrm{kU}$ per gram was purchased from Beijing Aoboxing Biotechnologies Inc. (Beijing, China). Fetal bovine serum was obtained from Wisent Inc. (Montreal, Quebec, Canada). EnzycChrom ${ }^{\mathrm{TM}}$ Galactose Assay Kit was purchased from BioAssay Systems (Hayward, CA, USA). Cell counting kit-8 (CCK-8) was bought from Dojindo Molecular Technologies, Inc. (Kyushu, Japan). Lactate dehydrogenase (LDH) kit was bought from Nanjing Jiancheng Bioengineering Institute (Nanjing, Jiangsu, China). Protein extraction kit was purchased from Beyotime Institute of Biotechnology (Shanghai, China). RNAprep pure Cell/Bacteria kit was purchased from Tiangen Biotech Co. Ltd. (Beijing, China). PrimeScript ${ }^{\mathrm{TM}}$ RT reagent Kit and SYBR® Premix Ex Taq ${ }^{\mathrm{TM}}$ (Tli RNaseH Plus) were purchased from Takara Bio Inc. (Kusatsu, Japan). Primary antibodies (GAPDH ab181602, occludin ab216327, claudin-1 ab15098) were purchased from Abcam plc. (Cambridge, UK). ZO-1 (AF5145) was purchased from Affinity Biosciences (Cincinnati, OH, USA). Goat anti-rabbit secondary antibody was purchased from Bioss Biotechnology Co., Ltd. (Beijing, China).

\section{Sample preparation}

The lactose-glycated caseinate was prepared as previously described. ${ }^{36}$ Briefly, the reaction mixture $(\mathrm{pH}$ 6.7) was prepared with caseinate $\left(50 \mathrm{~g} \mathrm{~L}^{-1}\right)$ and lactose $\left(80 \mathrm{~g} \mathrm{~L}^{-1}\right)$, heated at a water bath $\left(100{ }^{\circ} \mathrm{C}\right)$ for $3 \mathrm{~h}$ with constant stirring, rapidly cooled with an ice bath to stop the reaction, subjected to isoelectric precipitation followed by three isoelectric washings $(\mathrm{pH} 4.5)$ to remove free lactose, and then freeze-dried to obtain the glycated caseinate.

Both the glycated caseinate and caseinate $\left(50 \mathrm{~g} \mathrm{~L}^{-1}\right)$ were dispersed in water at $\mathrm{pH} 7.0$, hydrolyzed with trypsin (7 $\mathrm{kU} \mathrm{g}^{-1}$ protein) for $4 \mathrm{~h}$ at $37{ }^{\circ} \mathrm{C}$, heated at a boiling bath for $5 \mathrm{~min}$ to inactivate trypsin, cooled rapidly to $20{ }^{\circ} \mathrm{C}$, adjusted to $\mathrm{pH} 7.0$ with $0.5 \mathrm{~mol} \mathrm{~L}^{-1} \mathrm{NaOH}$, and then centrifuged at $5000 \times g$ for 20 min to obtain the corresponding GCN digest and CN digest, which were also freeze-dried.

\section{Chemical analyses}

Protein content was assessed using the Kjeldahl method and a conversion factor of $6.38 .^{37}$ After then, both the glycated caseinate and GCN digest were hydrolyzed with $2 \mathrm{~mol} \mathrm{~L}^{-1}$ trifluoroacetic acid at $100{ }^{\circ} \mathrm{C}$ for $4 \mathrm{~h}$, cooled to $20{ }^{\circ} \mathrm{C}$, and neutralized into $\mathrm{pH} 7.0$ with $0.5 \mathrm{~mol} \mathrm{~L}^{-1} \mathrm{NaOH}$. The obtained hydrolysates were detected for galactose contents using the Galactose Assay Kit and procedure provided by the kit producer. Lactose contents ( $\mathrm{g} \mathrm{kg}^{-1}$ protein) of the samples were thereby calculated chemically. 
Table 1 Primer sequences for TJ proteins and GAPDH

\begin{tabular}{|c|c|c|c|}
\hline Genes & & Primers $\left(5^{\prime}-3^{\prime}\right)$ & Product lengths (bp) \\
\hline \multirow[t]{2}{*}{ ZO-1 (mouse) } & For & AGCTGCCTCGAACCTCTACTCTAC & 176 \\
\hline & Rev & GCCTGGTGGTGGAACTTGCTC & \\
\hline & Rev & TGCCGACTCCTCTCACTGTAGC & \\
\hline \multirow[t]{2}{*}{ Occludin (mouse) } & For & TGGCTATGGAGGCGGCTATGG & 114 \\
\hline & Rev & AAGGAAGCGATGAAGCAGAAGGC & \\
\hline \multirow[t]{2}{*}{ Claudin-3 (mouse) } & For & GTCGGCCAACACCATCATCAGG & 143 \\
\hline & Rev & GGCAGGAGCAACACAGCAAGG & \\
\hline \multirow[t]{2}{*}{ Claudin-4 (mouse) } & For & TTCATCGGCAGCAACATCGTCAC & 113 \\
\hline & Rev & GCGAGCATCGAGTCGTACATCTTG & \\
\hline \multirow{2}{*}{ GAPDH } & For & GGTTGTCTCCTGCGACTTCA & 183 \\
\hline & Rev & TGGTCCAGGGTTTCTTACTCC & \\
\hline
\end{tabular}

\section{Cell line and culture conditions}

IEC-6 cells were bought from the American Type Culture Collection (Rockville, MD, US), and cultured in the DMEM containing $10 \%$ fetal bovine serum, $1 \%$ sodium pyruvate, and 0.1 units per $\mathrm{mL}$ bovine insulin. As recommended by the cell provider, IEC-6 cells were grown in a humidified $37{ }^{\circ} \mathrm{C}$ incubator with $5 \% \mathrm{CO}_{2}$.

\section{Cytotoxicity assay}

Cytotoxicity was measured by the CCK-8 assay according to the instructions of kit manufacturer. IEC- 6 cells $\left(3 \times 10^{3}\right.$ cells per well) were seeded in 96-well plates for $24 \mathrm{~h}$ prior to the assay, serum-starved for $12 \mathrm{~h}$, and incubated with acrylamide $(0,1.25$, $2.5,5$, and $10 \mathrm{mmol} \mathrm{L}^{-1}$ ) contained in fresh medium. The cells were further incubated for $24 \mathrm{~h}$. $100 \mu \mathrm{L}$ of $10 \%$ CCK-8 solution were added to each well, and the cells were incubated for $1.5 \mathrm{~h}$. Optical density values were measured at $450 \mathrm{~nm}$ on a microplate reader (Bio-Rad Laboratories, Hercules, CA, USA).

\section{Cell viability assay}

Cell viability was also measured by the CCK-8 assay. In brief, IEC- 6 cells $\left(3 \times 10^{3}\right.$ cells per well) were plated on 96 -well plates to confluence for $24 \mathrm{~h}$, starved for $12 \mathrm{~h}$, and incubated with fresh medium added or not with the two digests for a final concentration of $12.5-100 \mu \mathrm{g} \mathrm{mL}^{-1}$. The cells were incubated for 24 and $48 \mathrm{~h}$, and then incubated with $2.5 \mathrm{mmol} \mathrm{L}^{-1}$ acrylamide for $24 \mathrm{~h} .100 \mu \mathrm{L}$ of $10 \%$ CCK-8 solution were added into each well, and the cells were incubated for $1.5 \mathrm{~h}$. OD values at $450 \mathrm{~nm}$ was read by the microplate reader, and used to calculate cell viability (\%). The cells received the medium only served as control cells with a designated viability value of $100 \%$.

\section{Trans-epithelial electrical resistance assay}

Trans-epithelial electrical resistance (TEER) is a common integrity indicator of cell monolayers. TEER value of the cells was measured as previously described. ${ }^{38}$ IEC- 6 cells were grown on the Transwell inserts $(12 \mathrm{~mm}$ diameter, $0.4 \mu \mathrm{m}$ pore size, polyester membranes, Corning $)$ in 12 -well plates $\left(2 \times 10^{5}\right.$ cells per well) until the TEER value reached to $50 \Omega \mathrm{cm}^{-2}$, and then treated in the serum-free medium for $12 \mathrm{~h}$. Fresh medium with or without the two digests at a final concentration ranging 12.5$100 \mu \mathrm{g} \mathrm{mL} \mathrm{m}^{-1}$ was added into the apical transwell compartment for 12,24 , and $48 \mathrm{~h}$. The cells were further incubated with $2.5 \mathrm{mmol} \mathrm{L}{ }^{-1}$ acrylamide for $24 \mathrm{~h}$. TEER was measured by the Millicell-ERS2 Volt-Ohm Meter (Millipore, Bedford, MA, USA). Resistance values were recorded and calculated as $\Omega \mathrm{cm}^{-2}$ by multiplying the membrane filter area, and expressed as percentage as $\%$ TEER $=\left(\right.$ TEER $_{\text {treatment }} /$ TEER $\left._{\text {control }}\right) \times 100 \%$.

\section{Measurement of lactate dehydrogenase release}

$\mathrm{LDH}$ release into the culture medium is a cell injury indicator, and thus was measured to evaluate cell death. IEC- 6 cells $(3 \times$ $10^{3}$ cells per well) were seeded in 96-well plates to confluence for

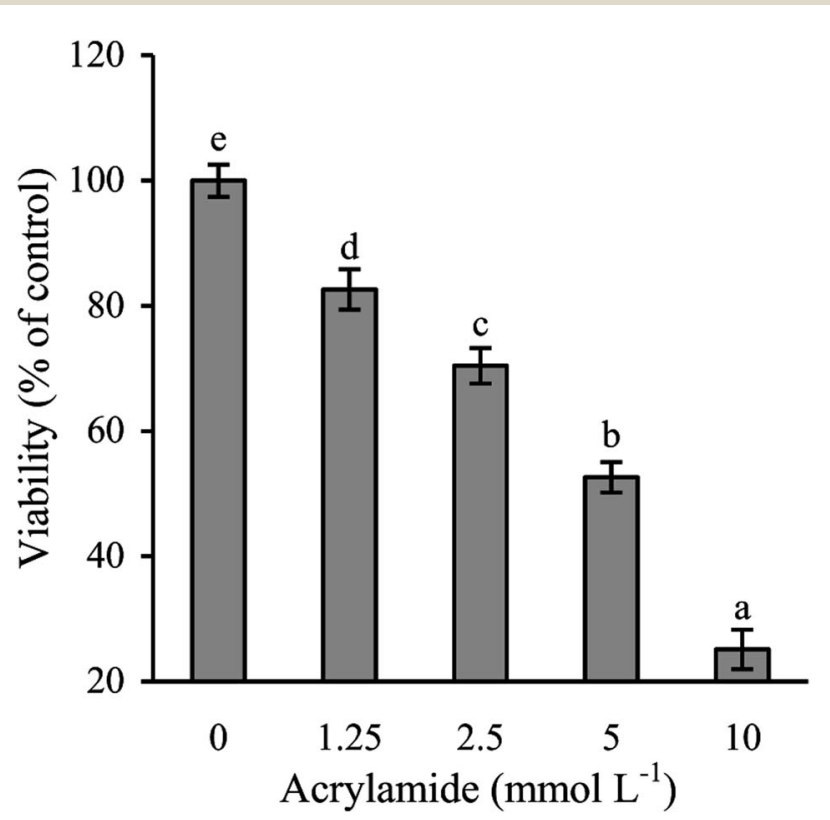

Fig. 1 Cytotoxicity (\%) of acrylamide (1.25-10 $\left.\mathrm{mmol} \mathrm{L}^{-1}\right)$ to IEC- 6 cells with treatment time of $24 \mathrm{~h}$. Different letters above the columns indicate that the mean values differ significantly $(p<0.05)$ 

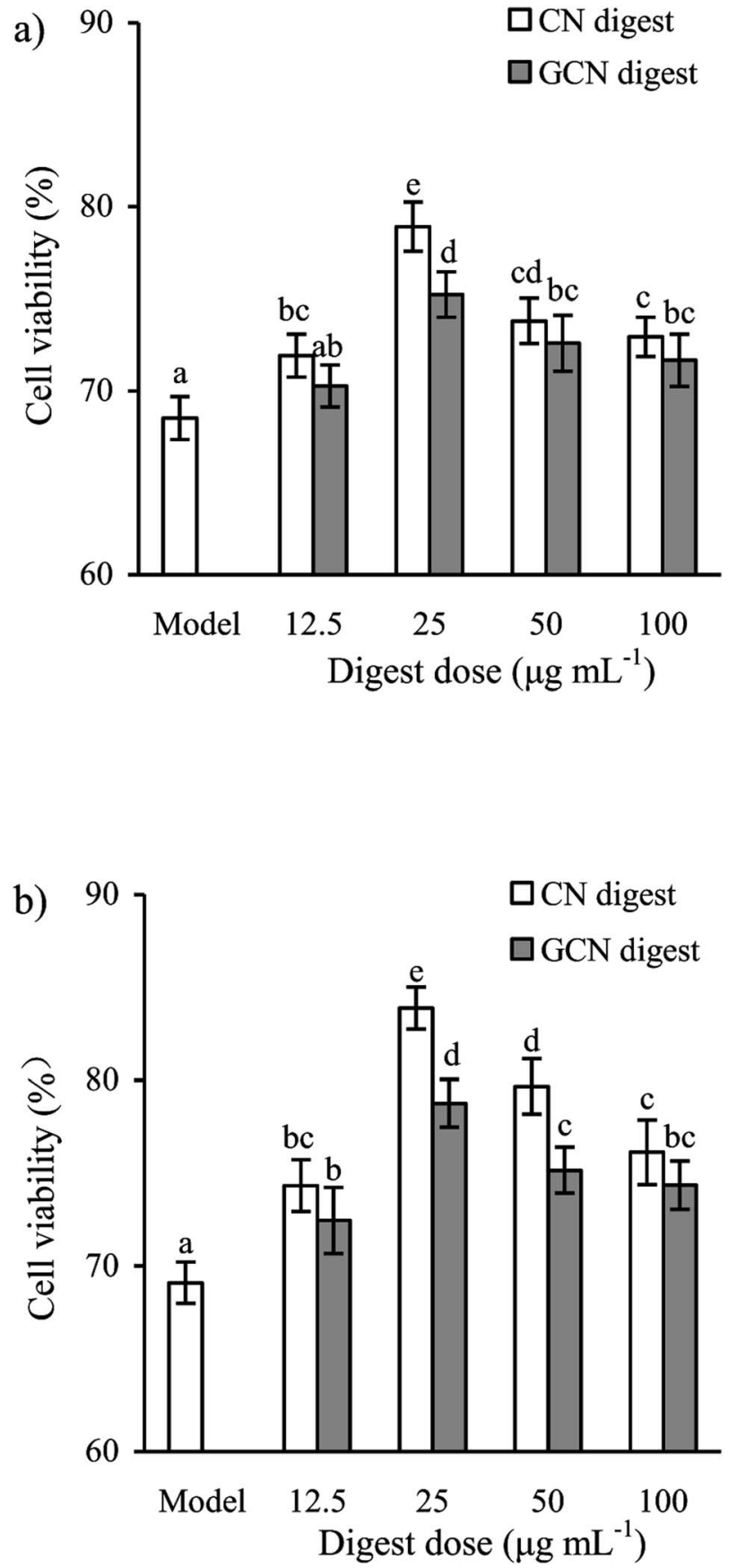

Fig. 2 Viability values (\%) of IEC- 6 cells treated with two digests for 24 (a) or $48 \mathrm{~h} \mathrm{(b)} \mathrm{and} \mathrm{then} \mathrm{treated} \mathrm{with} 2.5 \mathrm{mmol} \mathrm{L}^{-1}$ acrylamide for $24 \mathrm{~h}$. The statistical treatment was done comparing concentrations of different digests. Different letters above the columns indicate that the mean values differ significantly $(p<0.05)$.

$24 \mathrm{~h}$, starved for $12 \mathrm{~h}$ and incubated with fresh medium with or without the two digests at a final concentration ranging 12.5$100 \mu \mathrm{g} \mathrm{mL}{ }^{-1}$ for 24 and $48 \mathrm{~h}$. The cells were further incubated with $2.5 \mathrm{mmol} \mathrm{L}^{-1}$ acrylamide for $24 \mathrm{~h}$, and centrifuged at $190 \times$ $g$ for $5 \mathrm{~min}$. The collected supernatants were measured for LDH release using the lactate dehydrogenase assay kit and kit protocol. The cells received the medium only were designated as control cells with LDH release value of $100 \%$.

\section{Assay of paracellular permeability}

Epithelial permeability across IEC-6 cells was assessed by judging the passage of $4 \mathrm{kDa}$ fluorescein isothiocyanate (FITC)dextran from the apical to basolateral chambers of the Transwell permeable support inserts. Briefly, IEC- 6 cells $\left(2 \times 10^{5}\right.$ cells per well) were grown in $0.4 \mu \mathrm{m}$ pore inserts, treated with the two digests $\left(25 \mu \mathrm{g} \mathrm{mL}^{-1}\right)$ for 24 and $48 \mathrm{~h}$, and further incubated with
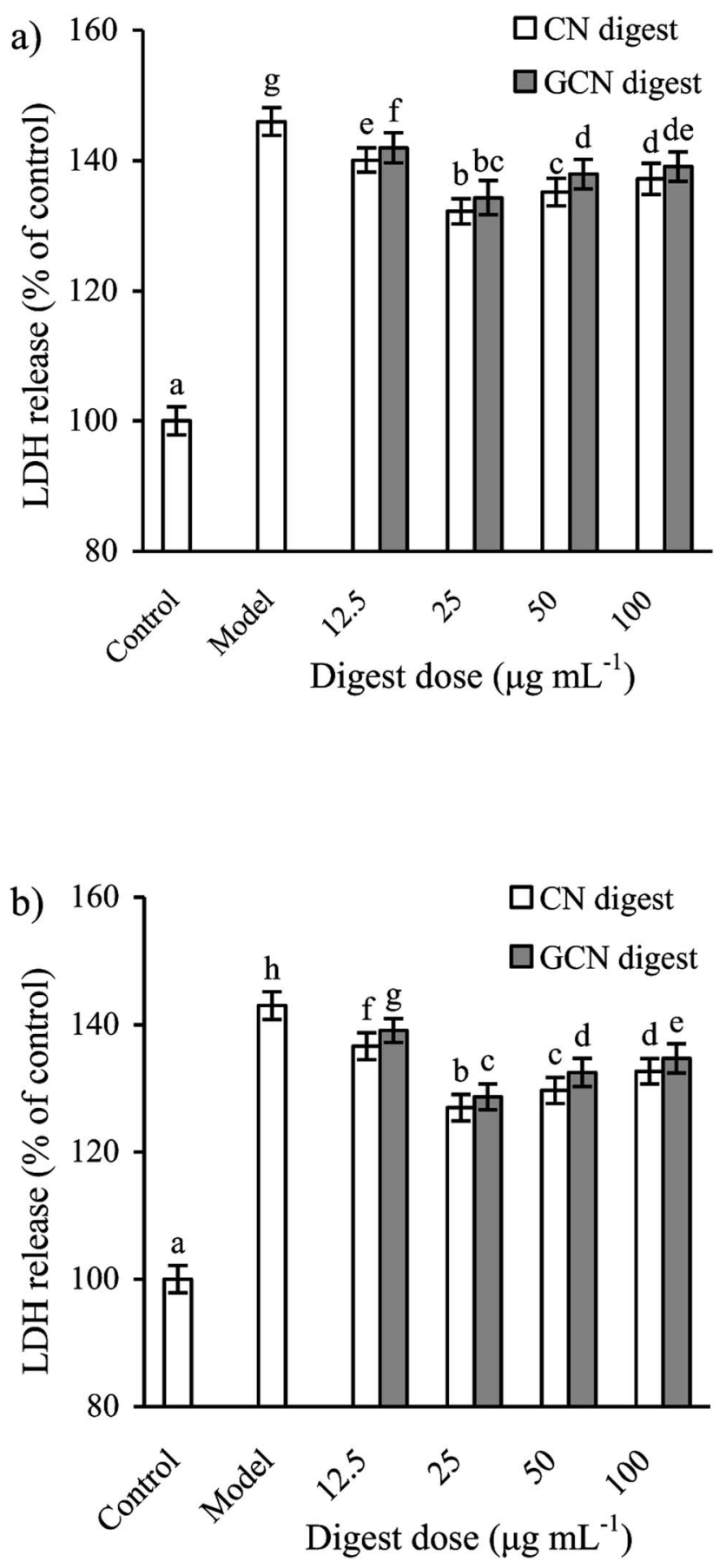

Fig. $3 \mathrm{LDH}$ release in IEC- 6 cells treated with two digests for 24 (a) and $48 \mathrm{~h} \mathrm{(b)} \mathrm{and} \mathrm{then} \mathrm{treated} \mathrm{with} 2.5 \mathrm{mmol} \mathrm{L}^{-1}$ acrylamide for $24 \mathrm{~h}$. The statistical treatment was done comparing concentrations of different digests. Different letters above the columns indicate that the mean values differ significantly $(p<0.05)$. 
$2.5 \mathrm{mmol} \mathrm{L}^{-1}$ acrylamide for $24 \mathrm{~h}$ as described previously. ${ }^{32}$ The $4 \mathrm{kDa}$ fluorescein isothiocyanate (FITC)-dextran was dissolved in the medium and used at final concentration of $0.5 \mathrm{mg} \mathrm{mL}^{-1}$ in the apical cell compartment. After $24 \mathrm{~h}$ of incubation, fluorescence was measured in the basal compartment using a fluorescent microplate reader (Infinite M200 pro, TECAN, Männedorf, Switzerland) at respective excitation and emission wavelengths of 490 and $520 \mathrm{~nm}$. Fluorescence levels were recorded as relative fluorescence units (RFU). Results were expressed as percentages of control value: \% cumulative flux of $4 \mathrm{kDa}$ FITC-dextran $(\mathrm{FD}-4)=\left(\mathrm{RFU}_{\text {treatment }} / \mathrm{RFU}_{\text {control }}\right) \times 100 \%$.

\section{Immuno-fluorescence assay}

Immuno-fluorescence image assay was used to verify the localization and production of TJ-associated $\mathrm{ZO}-1$, occludin, and claudin- 1 approximately. IEC- 6 cells (about $1 \times 10^{4}$ cells) were seeded on the coverslips (15 $\mathrm{mm}$ diameter, $0.13-0.16 \mathrm{~mm}$ thickness), treated with the two digests $\left(25 \mu \mathrm{g} \mathrm{mL}^{-1}\right)$ for 24 and $48 \mathrm{~h}$, and further incubated with $2.5 \mathrm{mmol} \mathrm{L}^{-1}$ acrylamide for $24 \mathrm{~h}$ as described previously. ${ }^{39}$ After these treatments, IEC- 6 cells were washed twice with PBS $\left(0.1 \mathrm{~mol} \mathrm{~L}^{-1}, \mathrm{pH} 7.2\right)$, fixed with $4 \%$ formaldehyde in the PBS for $10 \mathrm{~min}$, and permeabilized for $5 \mathrm{~min}$ at $20{ }^{\circ} \mathrm{C}$ using $0.2 \%$ Triton $\mathrm{X}-100$ in the PBS. The cells were blocked with $5 \%$ BSA in the PBS for $1 \mathrm{~h}$ at $20^{\circ} \mathrm{C}$, and incubated at $4{ }^{\circ} \mathrm{C}$ overnight with the primary antibodies anti-ZO-1, antioccludin, and anti-claudin-1 (1: 100 dilution by $5 \%$ BSA), followed by the biotinylated secondary antibody incubation $90 \mathrm{~min}$ and DAPI counterstaining. The TJ proteins were observed by an OLYMPUS IX71 fluorescence microscope (Olympus Corp., Tokyo, Japan) to obtain respective images.

\section{Quantitative real-time PCR assay}

The mRNA levels of the TJ genes of IEC- 6 cells were characterized by quantitative real-time PCR. IEC- 6 cells were treated with the two digests $\left(25 \mu \mathrm{g} \mathrm{mL} \mathrm{m}^{-1}\right)$ for $48 \mathrm{~h}$, and further incubated with $2.5 \mathrm{mmol} \mathrm{L}^{-1}$ acrylamide for $24 \mathrm{~h}$. With the kits' guidelines, total RNA was isolated with the RNAprep pure Cell/ Bacteria kit, and then reversed transcribed into complementary DNA (cDNA) with the PrimeScript ${ }^{\mathrm{TM}}$ RT reagent kit. The amplified cDNA was utilized for the template DNA and performed with specific primers (Table 1) for PCR assay. The SYBR ${ }^{\circledR}$ Premix Ex Taq ${ }^{\mathrm{TM}}$ (Tli RNaseH Plus) was used in real-time PCR analysis performed in 96-well plates for a total $25 \mu \mathrm{L}$ reaction mixtures, using an Applied Biosystems StepOnePlus Real-time PCR System (Life Technologies Corporation, Carlsbad, CA, USA). Glyceraldehyde-3-phosphate dehydrogenase (GAPDH) was amplified as internal control. Average quantification cycle threshold $(\mathrm{Ct})$ of triplicate samples was calculated as the quantity of gene product, and the relative mRNA expression levels were analyzed by a $2^{-\Delta \Delta \mathrm{Ct}}$ method. ${ }^{40}$ mRNA level in each sample was quantified by converting the cycle threshold.

\section{Western blot assay}

Expression levels of TJ proteins of IEC- 6 cells were determined using the western blot assay. IEC- 6 cells $\left(1 \times 10^{5}\right.$ cells per well $)$ were seeded in 6-well plates, treated with or without the two digests $\left(25 \mu \mathrm{g} \mathrm{mL}^{-1}\right)$ for 24 and $48 \mathrm{~h}$, further incubated with $2.5 \mathrm{mmol} \mathrm{L}^{-1}$ acrylamide for $24 \mathrm{~h}$, immediately rinsed with the ice-cold PBS, and lysed with a radio-immunoprecipitation assay (RIPA) lysis buffer (Beyotime Biotechnology, Shanghai, China), with PMSF $\left(1 \mathrm{mmol} \mathrm{L}^{-1}\right)$ on ice for $30 \mathrm{~min}$. Cell lysates were centrifuged at $4{ }^{\circ} \mathrm{C}$ for $5 \mathrm{~min}$ at $14000 \times g$ to collect supernatants for protein assay using the BSA Protein Assay Kit (Beyotime Biotechnology). Equal protein amount (50 $\mu \mathrm{g})$ for each sample was separated on 10\% SDS-PAGE gel (occludin and claudin-1) or on $7.5 \%$ SDS-PAGE gel (ZO-1). Proteins from the gel were transferred to the PVDF membrane, which were

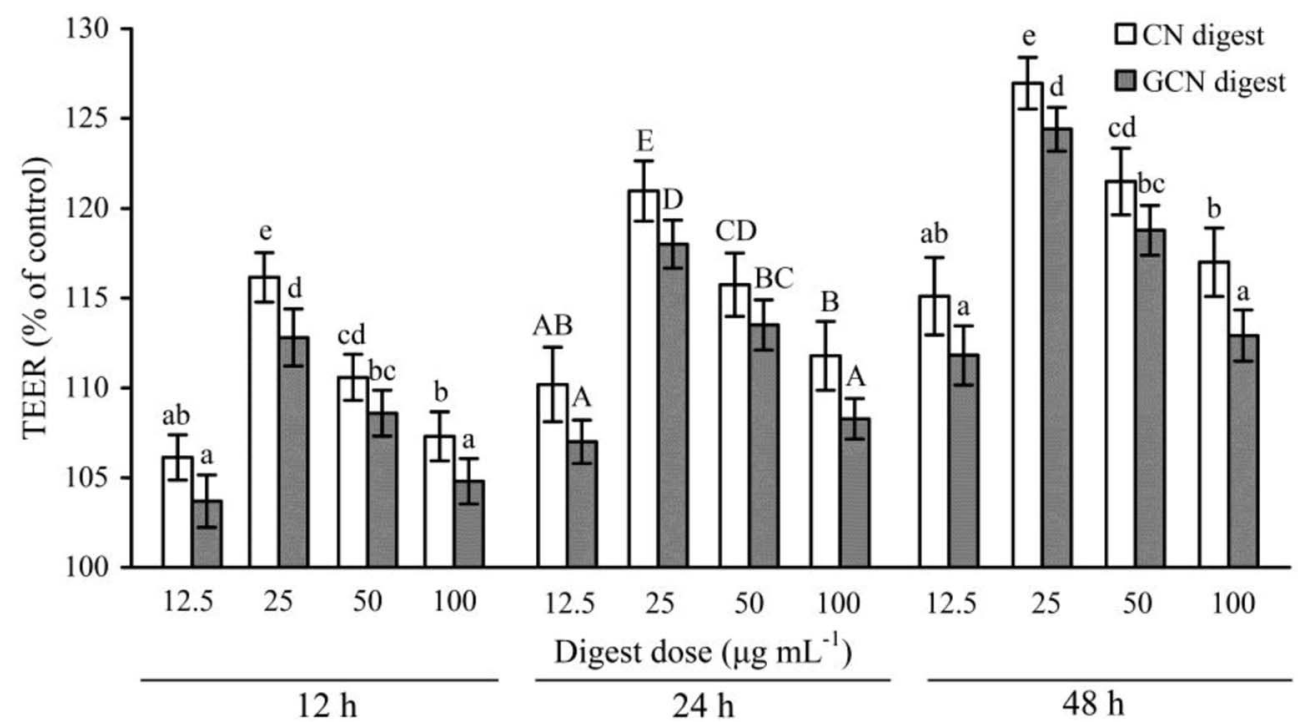

Fig. 4 Time-responses of TEER in IEC- 6 cells treated with two digests for $12-48 \mathrm{~h}$ and then treated with $2.5 \mathrm{mmol} \mathrm{L}^{-1}$ acrylamide for $24 \mathrm{~h}$. Data are expressed as percentage of TEER relative to the control. The statistical treatment was done comparing concentrations of different digests. Different letters above the columns indicate that the mean values differ significantly $(p<0.05)$. 
blocked with 5\% skimmed milk in the PBS containing $0.1 \%$ Tween-20 for $2 \mathrm{~h}$ at $37{ }^{\circ} \mathrm{C}$ and incubated with the primary antibodies ( 1 : 1000 dilution) at $4{ }^{\circ} \mathrm{C}$ overnight. The membranes were washed three times with the PBS containing $0.1 \%$ Tween20 , incubated with the secondary horseradish peroxidaseconjugated antibody ( $1: 1500$ dilution) for $1 \mathrm{~h}$ at $30{ }^{\circ} \mathrm{C}$. The enhanced chemiluminescence was covered on the membrane. Protein bands were detected using an Amersham Imager 600 (General Electric Company, Boston, MA, USA). Quantification was performed with Image $\mathrm{J}$ software (National Institutes of Health, Bethesda, MD, USA). The band density was normalized to the endogenous reference GAPDH.

\section{Statistical analysis}

The data from three independent experiments were reported as mean values \pm standard deviations and compared using the SPSS 16.0 software (SPSS Inc., Chicago, IL, USA). Significant differences (set at $p<0.05$ ) between the means of multiple groups were evaluated by one-way analysis of variance (ANOVA) with Duncan's multiple range tests.

\section{Results and discussion}

\section{Alleviated acrylamide cytotoxicity by the two digests}

Lactose was in fact conjugated with caseinate in this study via the conducted Maillard reaction, because lactose was detected in the glycated caseinate at a concentration of $12.6 \mathrm{~g} \mathrm{~kg}^{-1}$ protein. Consequently, the GCN digest was also detected to contain lactose at $10.8 \mathrm{~g} \mathrm{~kg}^{-1}$ protein. This fact meant that the CN digest was different from the GCN digest in this chemical feature. In other words, the GCN digest might have a different effect from the $\mathrm{CN}$ digest in IEC- 6 cells.

Acrylamide showed clear cytotoxicity to IEC-6 cells, as the obtained CCK-8 assay results indicated (Fig. 1). Acrylamide dose-dependently reduced cell viability of the treated cells. Exposed to $1.25,2.5,5$, and $10 \mathrm{mmol} \mathrm{L}^{-1}$ acrylamide for $24 \mathrm{~h}$, cell viability values decreased from $100 \%$ (the control cells) to $83 \%, 68 \%, 52 \%$, and $25 \%$, respectively. Acrylamide at $2.5 \mathrm{mmol}$ $\mathrm{L}^{-1}$ exerted a toxic effect on IEC- 6 cells with decreased cell viability of $32 \%$, and thus was used in later evaluation to injury the cells. Acrylamide doses other than $2.5 \mathrm{mmol} \mathrm{L}^{-1}$ induced lower or too higher cytotoxicity, and were no longer used in this study.

To select effective concentrations of the two digests for later experiments, the cells were also first treated with them and then incubated with $2.5 \mathrm{mmol} \mathrm{L}^{-1}$ acrylamide for $24 \mathrm{~h}$. The results (Fig. 2) showed that the CN digest and GCN digest at 12.5-100 $\mu \mathrm{g} \mathrm{mL} \mathrm{m}^{-1}$ resulted in cell viability values of $71.7-78.9 \%$ and $70.2-$ $75.3 \%$ ( $24 \mathrm{~h}$ ), or $74.3-83.9 \%$ and $72.4-78.8 \%$ (48 h), respectively. In these cases, the $\mathrm{CN}$ digest showed higher ability than the GCN digest to maintain cell viability values. Further results (Fig. 3) also indicated that $2.5 \mathrm{mmol} \mathrm{L}^{-1}$ acrylamide injured the cells and increased LDH release significantly. However, pretreatment with the two digests decreased $\mathrm{LDH}$ release efficiently, especially when the cells were incubated for $48 \mathrm{~h}$. The two digests thus had antagonistic effects (but in different extents) on the acrylamide-induced cell injury, leading to increased cell viability and decreased LDH release. This fact suggests that the Maillard-type caseinate glycation with lactose decreased the protective activity initially present in the native caseins.

Several chemicals such as acrylamide, indomethacin, and deoxynivalenol are able to induce cell injury. These foods such as roasted coffee and potato chips have higher acrylamide
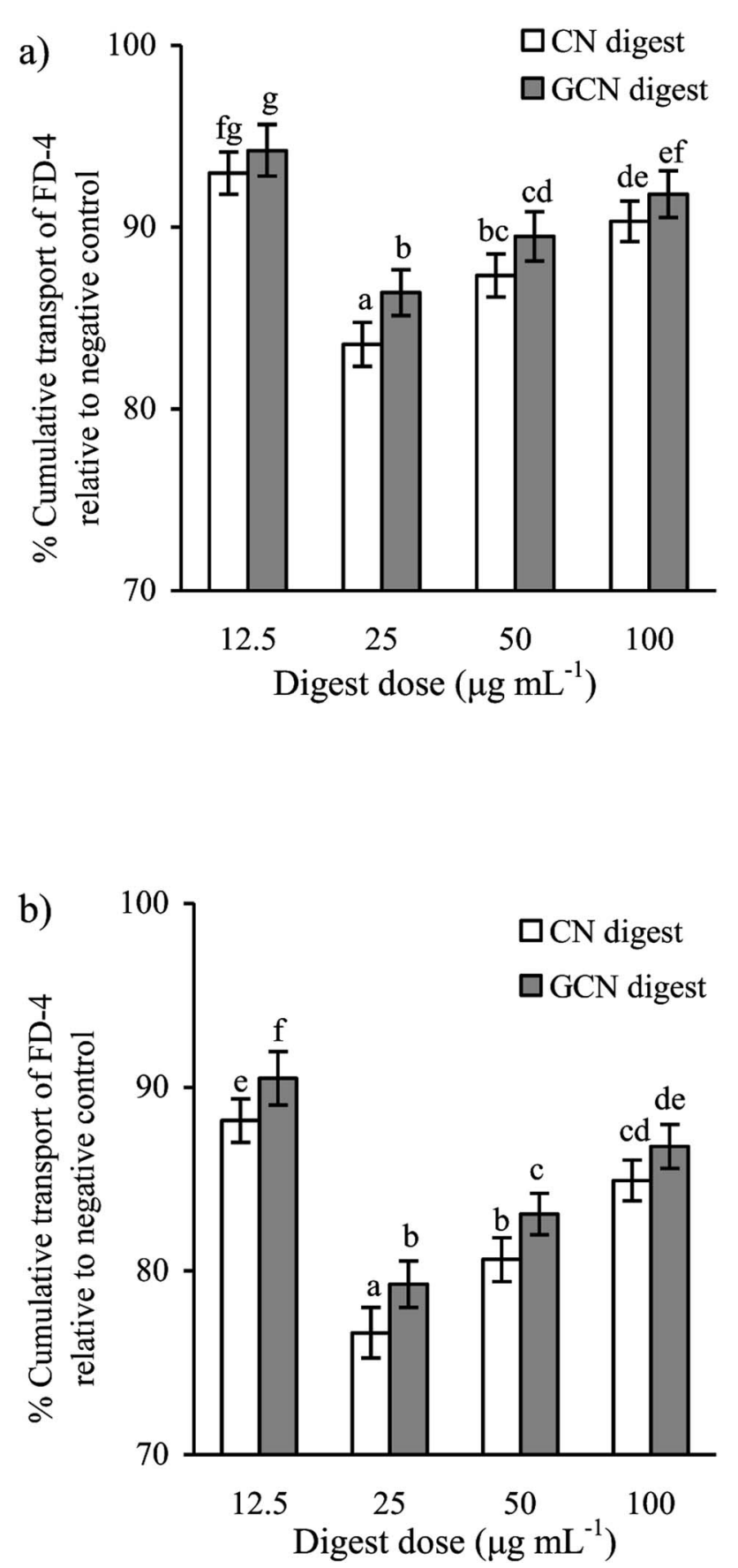

Fig. 5 Diffusion of FD-4 in IEC- 6 cells treated with two digests for 24 (a) or $48 \mathrm{~h}$ (b), and then treated with $2.5 \mathrm{mmol} \mathrm{L}^{-1}$ acrylamide for $24 \mathrm{~h}$. The statistical treatment was done comparing concentrations of different digests. Different letters above the columns indicate that the mean values differ significantly $(p<0.05)$. 

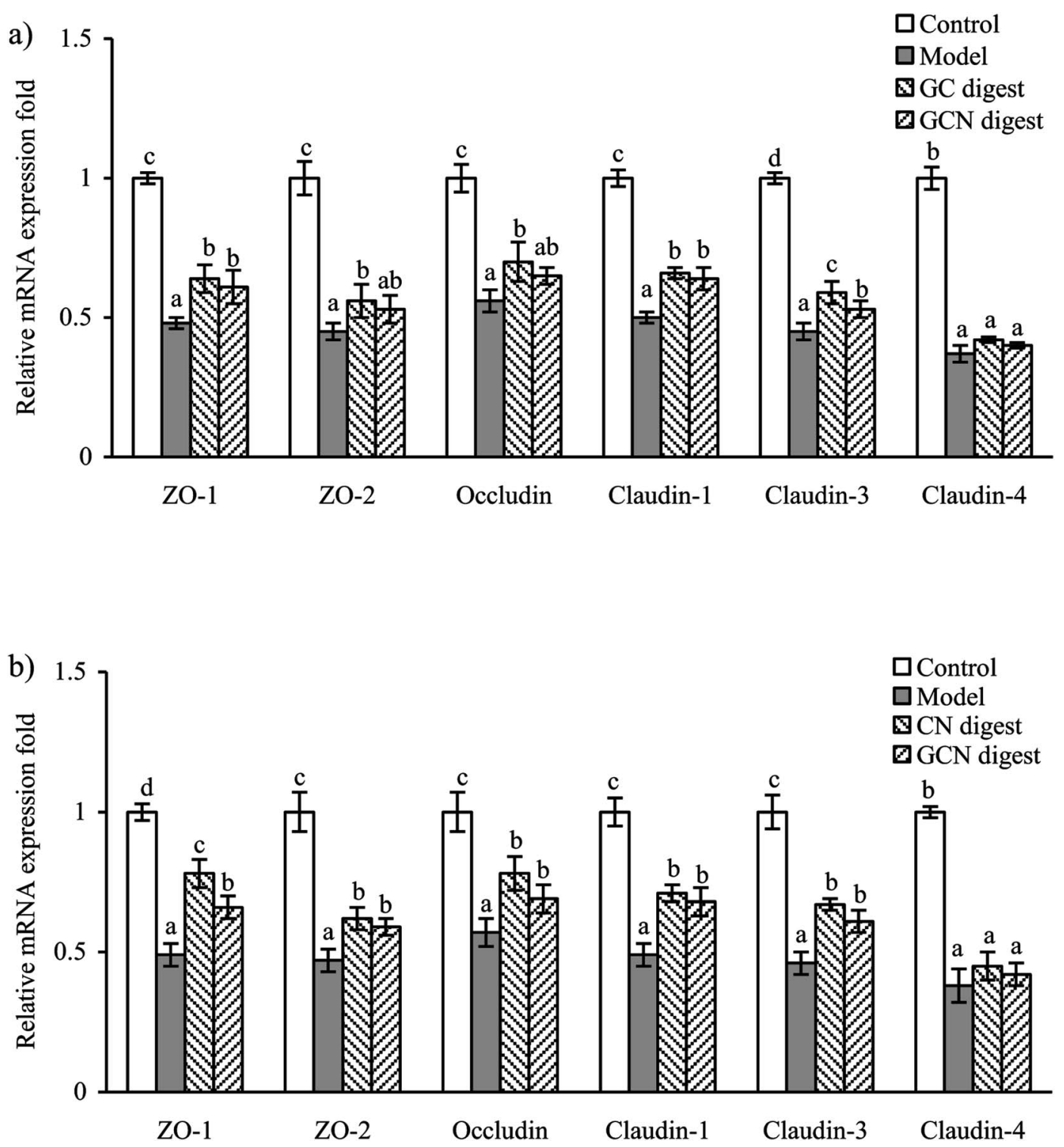

Fig. 6 Relative mRNA expression of TJ proteins in IEC- 6 cells treated with two digests for 24 (a) or $48 \mathrm{~h}$ (b), and then treated with $2.5 \mathrm{mmol} \mathrm{L}^{-1}$ acrylamide for $24 \mathrm{~h}$. The statistical treatment was done comparing concentrations of different digests. Different letters above the columns indicate that the mean values differ significantly $(p<0.05)$.

concentrations, and the children and adolescents tend to intake more acrylamide. ${ }^{6}$ The acrylamide-induced cytotoxicity in the intestine thus deserves special attention. Acrylamide at 2.5 and $5 \mathrm{mmol} \mathrm{L}^{-1}$ can induce Caco-2 and MDA-MB-231 cells injury with decreased cell viability. ${ }^{5,41}$ However, some compounds can ameliorate cell injury. Hispidin from the edible fungus Phellinus linteus can increase viability of the acrylamide-injured Caco-2 cells. ${ }^{5}$ Resveratrol is non-toxic to IPEC-J2 cells but can protect against the deoxynivalenol-induced cell damage. ${ }^{31}$ Cyanidin-3glucoside is capable of protecting against the acrylamideinduced oxidative stress in MDA-MB-231 cells, provoking enhanced cell viability and decreased $\mathrm{LDH}$ release. ${ }^{41}$ It is thus reasonable that acrylamide could also induce IEC- 6 cells injury, whilst the two digests gave preventive activities to alleviate this induced cell injury. Cell pre-treatment with the two digests brought about different preventive efficacies, which might mainly arise from the conducted Maillard-type caseinate glycation.

\section{Effects of the two digests on TEER and paracellular} permeability

To determine if the two digests could protect cell monolayers from the acrylamide-induced permeability injury, TEER assay was thus done for the treated or untreated cells. Effects of the two digests on TEER across the IEC- 6 cell monolayers are shown in Fig. 4. Regarding the acrylamide-treated cells alone, the two digests caused clear and sustained TEER value increases in the cells at each time point. Furthermore, prolonged treatment time led to increased TEER values. TEER values peaked at $48 \mathrm{~h}$ with the two digests at $25 \mu \mathrm{g} \mathrm{mL} \mathrm{mL}^{-1}$, with $126.9 \%$ (CN digest) and $124.4 \%$ (GCN digest) gain with respect to the TEER value using acrylamide only. Moreover, the $\mathrm{CN}$ digest was better than the 
GCN digest to increase TEER values of the cells, resulting in much improved barrier function.

Using the FD-4 diffusion assay, destruction of TJs in epithelial layer will result in increased paracellular permeability and enhanced FD-4 transport from the apical to basolateral wells, suggesting the destruction of intestinal epithelial monolayers. The cells treated with the two digests at each dose concentration had reduced cumulative flux, compared with the acrylamide-treated cells (flux value of 100\%) (Fig. 5). The two digests thus strengthened the cell monolayers via decreasing the FITC-dextran paracellular flux. Using the CN digest and GCN digest at $12.5-100 \mu \mathrm{g} \mathrm{mL}^{-1}$ for $24 \mathrm{~h}$, the respective flux values decreased to $83.5-92.5 \%$ and $86.4-94.1 \%$. Using these digest doses but $48 \mathrm{~h}$ treatment time, respective flux values decreased to $76.6-88.1 \%$ and $79.3-90.4 \%$. That is, longer treatment time led to decreased paracellular permeability (or better barrier function). The $\mathrm{CN}$ digest also showed better ability than the GCN digest to strengthen the cell monolayers, once again, suggesting the adverse impact of the Maillard-type caseinate glycation on preventive activity of the $\mathrm{CN}$ digest against the induced intestinal barrier dysfunction.

Several chemicals or dietary components are able to protect the induced intestinal barrier dysfunction. Lipopolysaccharide (LPS) at $100 \mu \mathrm{g} \mathrm{mL}{ }^{-1}$ can injury the Caco-2 cells with FITC- dextran permeability increase and TEER decrease; however, somatostatin is able to protect the LPS-induced barrier dysfunction. ${ }^{39}$ Resveratrol is also capable of protecting the deoxynivalenol-induced intestinal damage via increasing TEER value and decreasing paracellular permeability. ${ }^{32}$ If the Caco-2 cells are injured by dextran sulfate sodium (DSS), (-)-epigallocatechin-3-gallate, a polyphenolic component from tea, shows ability to decrease paracellular permeability. ${ }^{42}$ The present study shared similar results with these mentioned studies.

\section{Gene expression and distribution of $\mathrm{TJ}$ proteins in the cells}

The gut barrier is mostly formed by TJs, which are multi-protein complexes that link adjacent epithelial cells near their apical border. Six important TJ proteins in cell monolayers (ZO-1, ZO2 , occludin, claudin-1, claudin-3, and claudin-4) were thereby detected for their gene expression. Compared with the control cells without acrylamide and digest treatment, the model cells (exposed to acrylamide alone) had down-regulated mRNA expression of these TJ proteins. Regarding the model cells, those cells treated with the two digests for 24 and $48 \mathrm{~h}$ partially reversed the acrylamide-induced down-regulation of these proteins (Fig. 6). The two digests thus led to increased mRNA
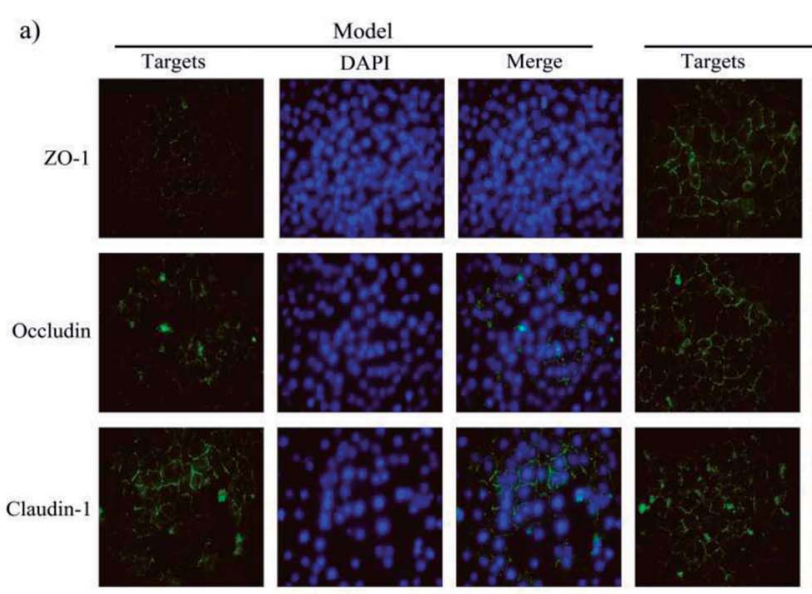

$\mathrm{CN}$ digest
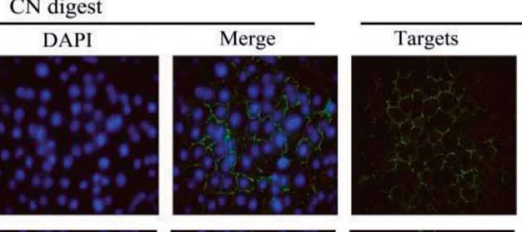

$\frac{\text { GCN digest }}{\text { DAPI }}$
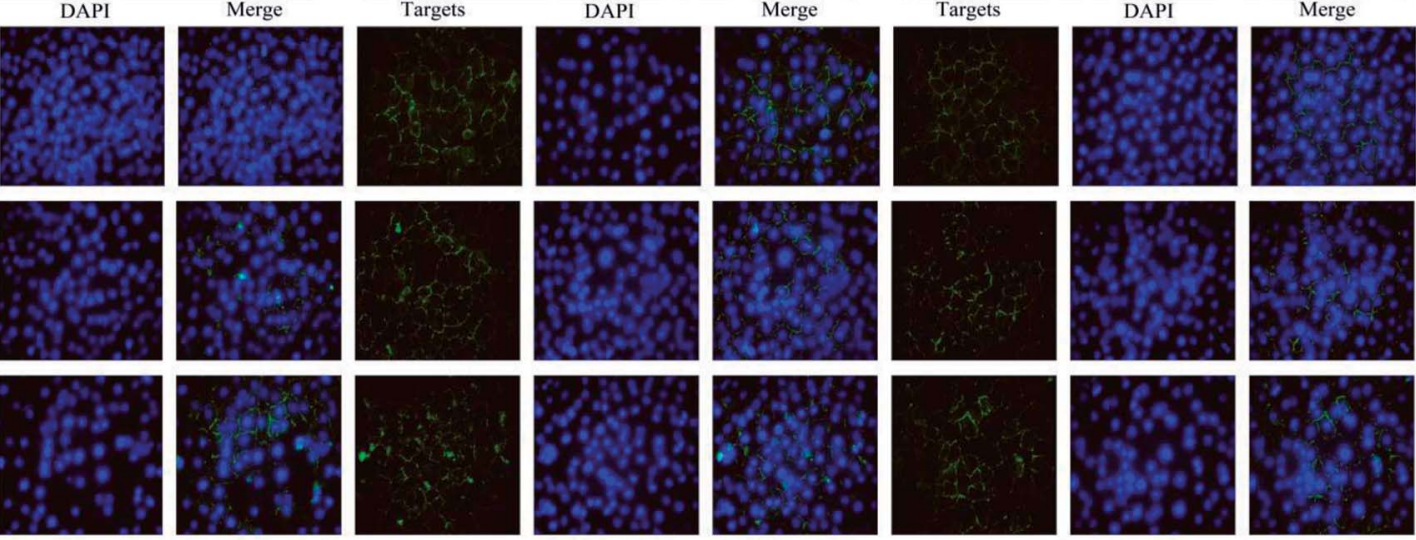

b)
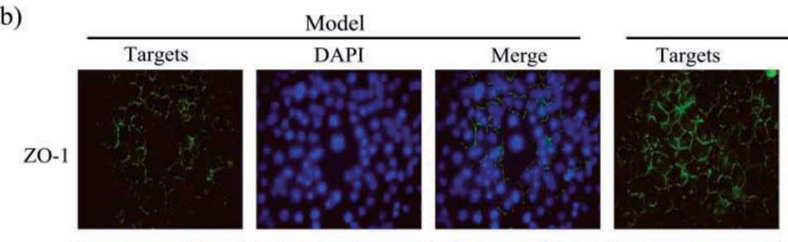

CN digest
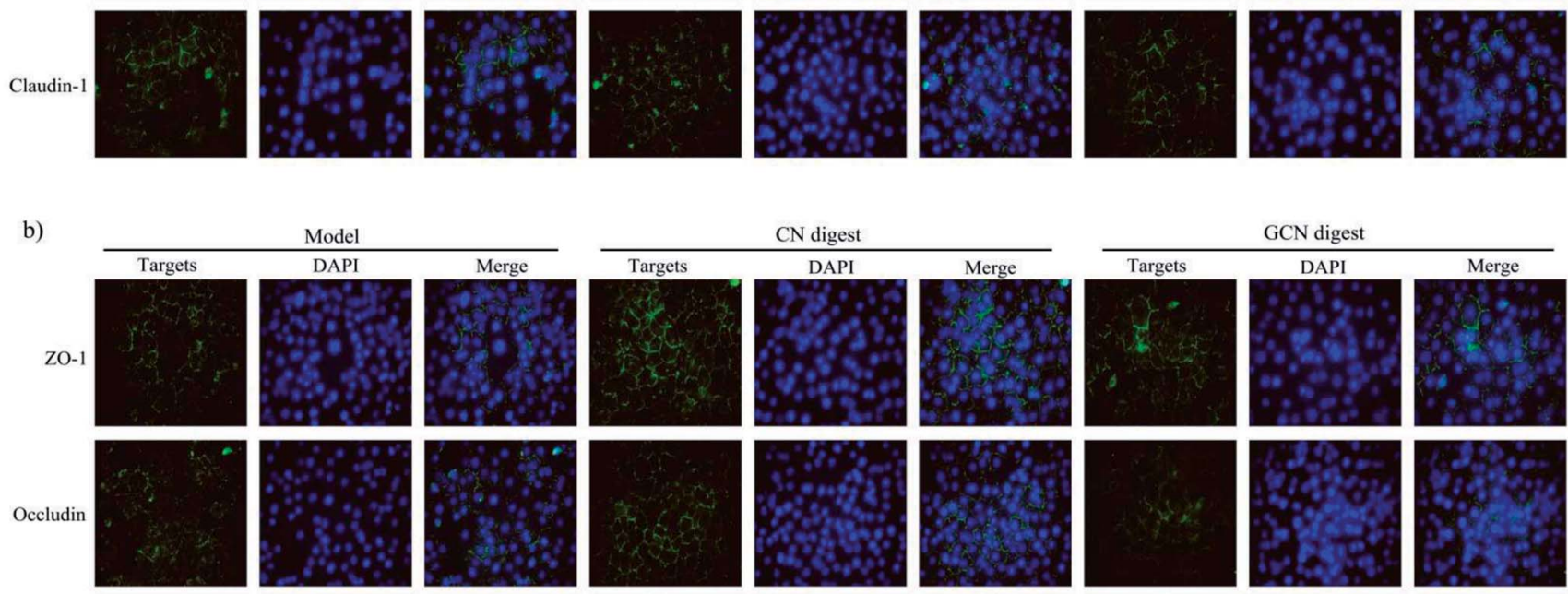

GCN digest
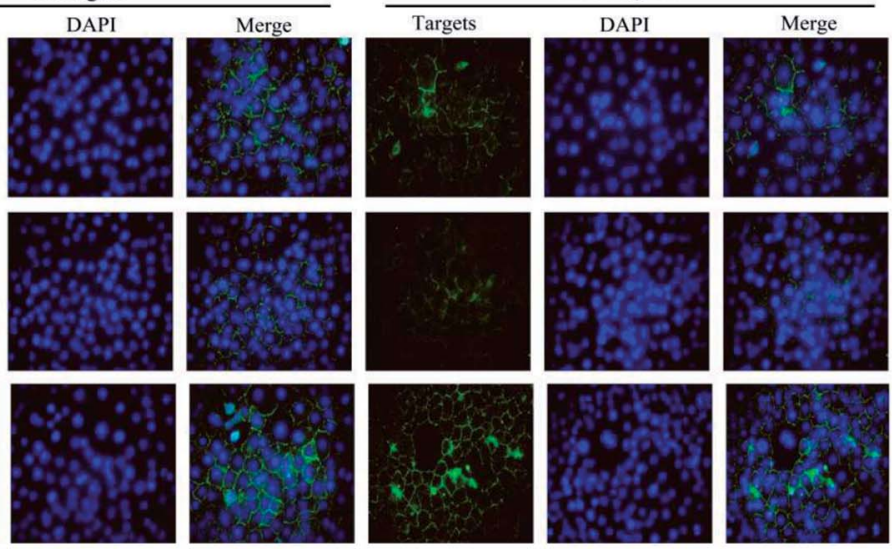

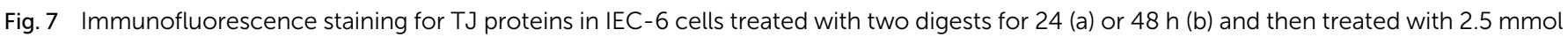

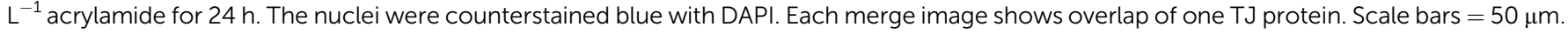


expression of these proteins. However, this assay also demonstrated that the $\mathrm{CN}$ digest was more effective than the GCN digest to increase mRNA expression of these proteins, suggesting the conducted caseinate glycation weakened initial activity of the native caseins. LPS also can decrease the mRNA expression of occludin and ZO-1 in IEC- 6 cells. However, cell treatment with baicalin may restore the mRNA expression of ZO-1. ${ }^{43}$ Similarly, 1,25-dihydroxyvitamin $D_{3}$ can enhance mRNA expression of ZO-1, occludin, and claudin-1 in the DSS-injured Caco- 2 cells. ${ }^{44}$

To examine if the two digests could maintain epithelial barrier function under the acrylamide stimulation, the distribution and expression of three TJ proteins (ZO-1, occludin, and claudin-1) in the cells were also assessed using an immunofluorescence method (Fig. 7), The results indicated that the three proteins were localized in the intercellular junction and distributed along the cell membrane, which was observed as a honeycomb linear fluorescence. The cells exposed to acrylamide at $2.5 \mathrm{mmol} \mathrm{L}^{-1}$ for $24 \mathrm{~h}$ had markedly disrupted $\mathrm{TJ}$ network, while the normal distribution of these proteins was replaced by an aberrant pericellular location. Referring the acrylamide-treated cells alone, the cells treated with the two digests showed substantially increased secretion of these proteins. Prolonged cell treatment time $(48 \mathrm{~h})$ led to further increased protein secretion (Fig. 7a versus Fig. 7b). The two digests thus markedly attenuated the acrylamide-induced TJ abnormalities, resulting in improved barrier function. Of interest, the $\mathrm{CN}$ digest was roughly observed to bring more secretion increases in ZO-1, occludin, and claudin-1, suggesting the conducted caseinate glycation decreased this activity of the GCN digest. In the past immunofluorescence assays, LPS was evidenced to disturb ZO-1 and occludin at the cellular borders, and tert-butyl hydroperoxide could decrease ZO-1 and occludin secretion in Caco-2 cells. ${ }^{39,45}$ Furthermore, the propolis extracts rich in polyphenols could bring about improved TJ structure for the injured Caco- 2 cells. ${ }^{45}$

\section{Expression of TJ-associated proteins in the cells}

Expression of ZO-1, occludin, and claudin-1 were also assessed using the western blot assay (Fig. 8). The cells treated with the two digests showed increased expression of these proteins, regarding the model cells treated with acrylamide only. In brief, the $\mathrm{CN}$ digest at 24 and $48 \mathrm{~h}$ led to increased ZO-1, occludin, claudin-1 expression by $51.1-53.4 \%, 23.0-26.3 \%$, and $64.5-$ $68.6 \%$, while the GCN digest at same time point increased their expression by $25.8-31.3 \%, 11.5-17.7 \%$, and $55.1-59.9 \%$, respectively $(p<0.05)$. The $\mathrm{CN}$ digest was also notable for its a)
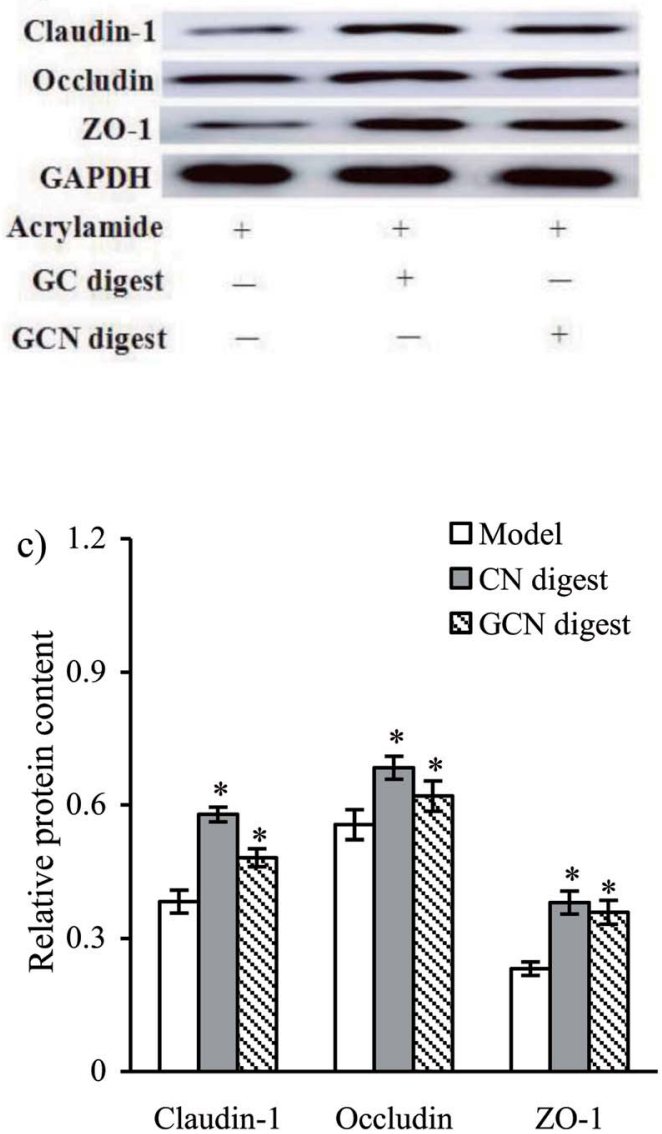

b)

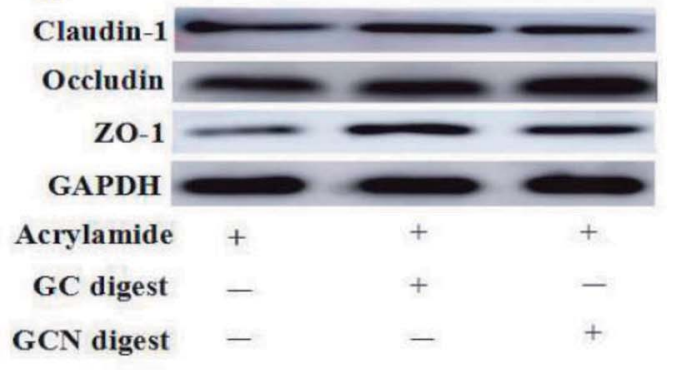

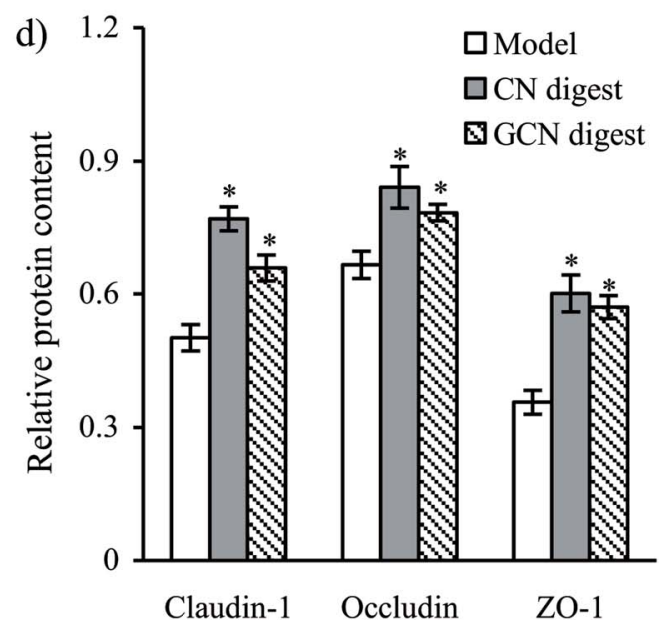

Fig. 8 TJ protein expression and their change levels in IEC-6 cells treated with two digests for 24 (a and c) or $48 \mathrm{~h}$ (b and d) and then treated with $2.5 \mathrm{mmol} \mathrm{L}^{-1}$ acrylamide for $24 \mathrm{~h} .{ }^{*} p<0.05$ compared with model group. 
higher ability than the GCN digest to enhance the expression of these proteins, once again, evidencing the adverse impact of the conducted caseinate glycation on preventive efficacy of caseinate digest against the induced intestinal barrier dysfunction.

Several dietary components are able to enhance TJ protein expression and thereby protect the induced intestinal barrier dysfunction. Beta-casofensin can increase occludin expression in the indomethacin-induced intestinal lesions in rats. ${ }^{31}$ Baicalin can protect the LPS-induced intestinal epithelial cell injury, via increasing claudin-3, occludin, and ZO-1 expression. ${ }^{43}$ Besides, it was also found that the oxyresveratrol-treated Caco- 2 cells gave rise to over-expressed $\mathrm{ZO}-1$, occludin, and claudin-1..$^{35}$ It is thus reasonable that the two digests had preventive effects against the acrylamide-induced intestinal barrier dysfunction via enhancing the expression of the three important TJ proteins.

\section{Conclusion}

With these assessed indices, acrylamide was evidently able to injury IEC-6 cells with barrier dysfunction including TEER decrease and especially epithelial permeability increase. However, both the $\mathrm{CN}$ digest and GCN digest could markedly alleviate this induced barrier dysfunction, via partially restoring the decreased TEER and increased epithelial permeability. The two digests (especially the $\mathrm{CN}$ digest) up-regulated the expression of $\mathrm{TJ}$ proteins to keep $\mathrm{TJ}$ integrity, and thus improved barrier function of the cells. Considering that the GCN digest was a tryptic derivative from Maillard-type glycated caseinate, another adverse effect of the Maillard reaction on food proteins was thus highlighted. That is, Maillard-type protein glycation might confer protein digest with impaired preventive efficacy to restore intestinal barrier function if intestinal epithelial cells are injured.

\section{Conflicts of interest}

The authors declare no conflict interest.

\section{Acknowledgements}

This work was funded by the National High Technology Research and Development Program ("863" Program) of China (Project No. 2013AA102205). The authors thank the anonymous referees for their valuable advice.

\section{References}

1 D. V. Zyzak, R. A. Sanders, M. Stojanavic, D. H. Tallmadge, B. L. Eberhart, D. K. Ewald, D. C. Gruber, T. R. Morsch, M. A. Strothers, G. P. Rizzi and M. D. Villagran, J. Agric. Food Chem., 2003, 51, 4782-4787.

2 M. Y. Zhao, P. P. Wang, Y. C. Zhu, X. Liu, X. S. Hu and F. Chen, J. Funct. Foods, 2015, 14, 95-101.

3 W. Chen, H. M. Su, Y. Xu, T. Bao and X. D. Zheng, Food Chem., 2016, 196, 943-952.
4 R. Pernice, J. Hauder, P. Koehler, P. Vitaglione, V. Fogliano and V. Somoza, Mol. Nutr. Food Res., 2009, 53, 1540-1550.

5 F. Sorgel, R. Weissenbacher, M. Kinzig-Schippers, A. Hofmann, M. Illauer, A. Skott and C. Landersdorfer, Chemotherapy, 2002, 48, 267-274.

6 V. Gökmen, Acrylamide in food: analysis, content and potential health effects, CA, USA, 2016.

7 E. Tomaszewska, P. Dobrowolski, I. Puzio, L. Prost, P. Kurlak, P. Sawczuk, B. Badzian, M. Hulas-Stasiak and K. Kostro, J. Physiol. Pharmacol., 2014, 65, 107-115.

8 E. Dybing, P. B. Farmer, M. Andersen, T. R. Fennell, S. P. Lalljie, D. J. Müller, S. Olin, B. J. Petersen, J. Schlatter, G. Scholz, J. A. Scimeca, N. Slimani, M. Törnqvist, S. Tuiitelaars and P. Verger, Food Chem. Toxicol., 2005, 43, 365-410.

9 L. E. Lyn-Cook Jr, E. Tareke, B. Word, A. Starlard-Davenport, B. D. Lyn-Cook and G. J. Hammons, Toxicol. Ind. Health, 2011, 27, 11-18.

10 X. W. Mu, C. Pan, S. Y. Zheng, Y. Alhamdi, B. W. Sun, Q. K. Shi, X. Wang, Z. W. Sun, C. H. Toh and G. Z. Wang, PLoS One, 2014, 9, e104032.

11 K. R. Groschwitz and S. P. Hogan, J. Allergy Clin. Immunol., 2009, 124, 3-20.

12 J. R. Turner, Nat. Rev. Immunol., 2009, 9, 799-809.

13 T. Suzuki, Cell. Mol. Life Sci., 2013, 70, 631-659.

14 G. Yang, S. Bibi, M. Du, T. Suzuki and M. J. Zhu, Crit. Rev. Food Sci. Nutr., 2017, 57, 3830-3839.

15 C. Geraud, K. Evdokinov, B. K. Straub, W. K. Peitsch, A. Demory, Y. Dorflinger, K. Schledzewski, A. Schmieder, P. Schemmer, H. G. Augustin, P. Schirmacher and S. Goerdt, PLoS One, 2012, 7, e34206.

16 X. N. Han, E. Mann, S. Gilbert, Y. F. Guan, K. A. Steinbrecher, M. H. Montrose and M. B. Cohen, PLoS One, 2011, 6, e16139. 17 K. Hodges and R. Gill, Gut Microbes, 2010, 1, 4-21.

18 S. Zeissig, D. Bünzel, D. Günzel, J. Richter, J. Mankertz, U. Wahnschaffe, A. J. Kroesen, M. Zeitz, M. Fromm and J. D. Schulzke, Gut, 2007, 56, 61-72.

19 K. Mineta, Y. Yamamoto, Y. Tamazaki, H. Tanaka, Y. Tada, K. Saito, A. Tamura, M. Igarashi, T. Endo, K. Takeuchi and S. Tsukita, FEBS Lett., 2011, 585, 606-612.

20 M. Furuse, T. Hirase, M. Itoh, A. Nagafuchi, S. Yonemura, S. Tsukita and S. Tsukita, J. Cell Biol., 1993, 123, 1777-1788.

21 X. Cong, Y. Zhang, N. Y. Yang, J. Li, C. Ding, Q. W. Ding, Y. C. Su, M. Mei, X. H. Guo, L. L. Wu and G. Y. Yu, J. Cell Sci., 2013, 126, 1109-1121.

22 S. Citi, H. Sabanay, R. Jakes, B. Geiger and J. Kendrick-Jones, Nature, 1988, 333, 272-276.

23 E. Cario, G. Gerken and D. K. Podolsky, Gastroenterology, 2004, 127, 224-238.

24 R. Nagpal, P. Behare, R. Rana, A. Kumar, M. Kumar, S. Arora, F. Morotta, S. Jain and H. Yadav, Food Funct., 2001, 2, 18-27. 25 A. B. Nongonierma and R. J. FitzGerald, J. Funct. Foods, 2015, 17, 640-656.

26 S. Kim, J. Je and S. Kim, J. Nutr. Biochem., 2007, 18, 31-38.

27 F. Chevalier, J. M. Chobert, Y. Popineau, M. G. Nicolas and T. Haertlé, Int. Dairy J., 2011, 11, 145-152. 
28 C. M. Brands, G. M. Alink, M. A. van Boekel and W. M. Jongen, J. Agric. Food Chem., 2000, 48, 2271-2275.

29 R. A. Siciliano, M. F. Mazzeo, S. Arena, G. Renzone and A. Scaloni, Food Res. Int., 2013, 54, 988-1000.

30 S. P. de la Cueva, I. Seiquer, M. Mesías, J. Á. Rufián-Henares and C. Delgado-Andrade, Foods, 2017, 6, 5.

31 C. Bessette, B. Benoit, S. Sekkal, J. Bruno, M. Estienne, J. Leonil, L. Ferrier, V. Theodorou and P. Plaisancie, Mol. Nutr. Food Res., 2016, 60, 823-833.

32 K. H. Ling, M. L. Y. Wan, H. EI-Nezami and M. F. Wang, Chem. Res. Toxicol., 2016, 29, 823-833.

33 G. Boudry, M. K. Hamilton, M. Chichlowski, S. Wickramasinghe, D. Barile, K. M. Kalanetra, D. A. Mills and H. E. Raybould, J. Dairy Sci., 2017, 100, 1-11.

34 I. Sukhotnik, D. Moati, R. Shaoul, B. Loberman, Y. Pollak and B. Schwartz, Food Nutr. Res., 2018, 62, e1327.

35 H. Jo, D. Hwang, J. K. Kim and Y. H. Lim, Food Chem. Toxicol., 2017, 108, 203-213.

36 X. P. Wang and X. H. Zhao, J. Sci. Food Agric., 2017, 97, 26172622.
37 AOAC International, Official methods of analysis, AOAC International, Gaithersburg, MD, 18th edn, 2005.

38 W. D. Xiao, W. Chen, L. H. Sun, W. S. Wang, S. W. Zhou and H. Yang, Mol. Cell. Neurosci., 2011, 46, 527-534.

39 S. Lei, T. M. Cheng, Y. D. Guo, C. Li, W. D. Zhang and F. C. Zhi, Eur. J. Cell Biol., 2014, 93, 299-307.

40 K. J. Livak and T. D. Schmittgen, Methods, 2001, 25, 402-408. 41 J. Song, M. Y. Zhao, X. Liu, Y. C. Zhu, X. S. Hu and F. Chen, Food Chem. Toxicol., 2013, 58, 306-310.

42 Z. T. Bitzer, R. J. Elias, M. Vijay-Kumar and J. D. Lambert, Mol. Nutr. Food Res., 2016, 60, 2267-2274.

43 J. Chen, R. Zhang, J. Wang, P. Yu, Q. Liu, D. Zeng, H. P. Song and Z. Y. Kuang, Can. J. Physiol. Pharmacol., 2015, 93, 233237.

44 H. W. Zhao, H. Zhang, H. Wu, H. Li, L. Liu, J. Guo, C. Y. Li, D. Q. Shih and X. L. Zhang, BMC Gastroenterol., 2012, 12, 57.

45 K. Wang, X. L. Jin, Y. F. Chen, Z. H. Song, X. S. Jiang, F. L. Hu, M. A. Conlon and D. L. Topping, Nutrients, 2016, 8, 272. 